\title{
“INTERNATIONAL” STYLE ARCHITECTURE IN THE 1930s JAPAN: THE VERNACULAR AND MONUMENTALITY
}

\author{
A B S T R A C T
}

After mastering Western architecture in the 1910s, Japanese top architects have been confronted with two problems: creating their own style based on Japanese traditions and climatic or seismological conditions and educating common people on taste for architecture beyond superficial imitation of the Western one. First of all, an elite and initially expressionist architect Horiguchi Sutemi discussed non-urban-ness that connects Japanese tearooms and Dutch rural houses. This was through his modernist interpretation of function, his experience in the Netherlands and his reaction against the administrative viewpoints on city and architecture in the 1920s. Secondly, despite his former distant stance on monumentality, his request of the world-wide supreme expression to some projected monuments revitalized his own inclination. Seemingly his attitudes toward monumentality changed and the property of the monuments that honored the war victims or enhanced national prestige opposed the "international" feature of modern architecture. Although these points may hide his consistency, we can find his continuous dualism: one is the functionality that prevailed over architectural discourses at that time including Horiguchi himself and another is his expression that provided a local vernacular practice with the position in the world. These arguments enable us to cast a potential understanding among modern architects in those days in a new light.

KEY WORDS 


\section{INTRODUCTION: ARCHITECTURAL STYLES IN MODERN JAPAN}

Modern architecture, especially modernist architecture, has rationalized its universality by the common conditions of materials, industries and construction processes throughout the globe. However, in the countries that developed later, there probably existed a call to establish their national histories and styles that overrode mere local practices toward world history. For example, by the 1910s many Japanese mainstream architects had mastered European architectural styles. They came to find earthquake as their own grounds to design and continued to define Japanese national architectural history and style based on their insight ${ }^{1}$. At the same time, Japanese historians of art and architecture were defining the uniqueness of their national history and claimed that Japan had been free from Chinese and Korean influences. Moreover, Japanese common building practice focused more on visible shapes than on ideas and influence of European Secession Movements, that came into fashion in suburban houses of Tokyo and other big cities. This tendency for appearance to precede concepts was clear in the colorful pavilions arranged at the site of domestic exhibitions as cartography of styles and tastes. That was repelled by authoritarian architects. They advocated the spirit of orthodox styles to promote the architectural taste among Japanese and the problem of style became the main theme around the architectural circle.

In this paper an elite architect Horiguchi Sutemi (1895-1984) in his early days will be discussed. Horiguchi graduated from Tokyo Imperial University as a member of the first Japanese architectural movement Bunriha Kenchiku Kai (Secessionist Architectural Group), active from 1920 to 1928. They can be regarded as Expressionists because of their attitude: they advocated architects' selves while the mainstream Structural Faction pursued efficient and resistant construction as a means to increasing the nation's wealth. Then the group came to assume another Expressionistic feature: their design itself. The members frequently referred to their schooldays experience in Qingdao, a Chinese city colonized by Germans, where it was swept by the deformed style of Reformarchitektur that had prevailed earlier in northern Germany apart from Expressionism (Fig. 1). Its influences were apparent in their design at their beginning (Fig. 2), but they tried the Expressionist design soon after that (Fig. 3). Horiguchi has drawn a considerable attention from today's discussion on Japaneseness, for example that of an architect Isozaki Arata (1931-)². This discussion has regarded Japaneseness in those days as parallel with Overcoming the Modern, one of the concepts that led a national antagonism toward the West ${ }^{3}$. 
There are two foci in this discussion. First, it will be looked at Horiguchi's discussion on non-urban-ness presented in 1927 which was based on his experience in Europe in 1923. He was referring to his experience in the Netherlands when he emphasized local and primordial elements of architecture and later this interest was succeeded to his enthusiasm of Japanese tearooms. His bold interpretation of function connected Dutch rural houses to Japanese tearooms. The second focus is Horiguchi's adoption of monumentality in his design of 1939 despite his distant stance on monumentality in the 1927 discussion. We will explore his consistency through the analysis of his monumentality in contrast to functionality. As he attached an importance on expression that the World would accept, he reduced the meaning of functionality and took monuments as assuming an expression.

\section{WABI AND SABI THROUGH DUTCH EXPERIENCE: 1920s}

While Horiguchi had a plan to study in Germany when he travelled to Europe, he decided to return to Japan in 1924 after the Great Kanto Earthquake of 1923. Post-war architectural historians and Horiguchi himself mentioned that his visit to Parthenon of Athens inspired as well as forced him to stop following European traditions and turn back to his roots in Japan, such as tearooms. However, it is doubted that this episode is either fictive or edited when one reads that he repeatedly visited the Netherlands "as far as (his) visa permit(ted)" and prepared to introduce contemporary Dutch architecture through lecture and publication right after his homecoming ${ }^{5}$. His only publication that introduced overseas architecture in 1924 referred solely to the Netherlands even though there was a plan of serial publication on German-speaking countries.

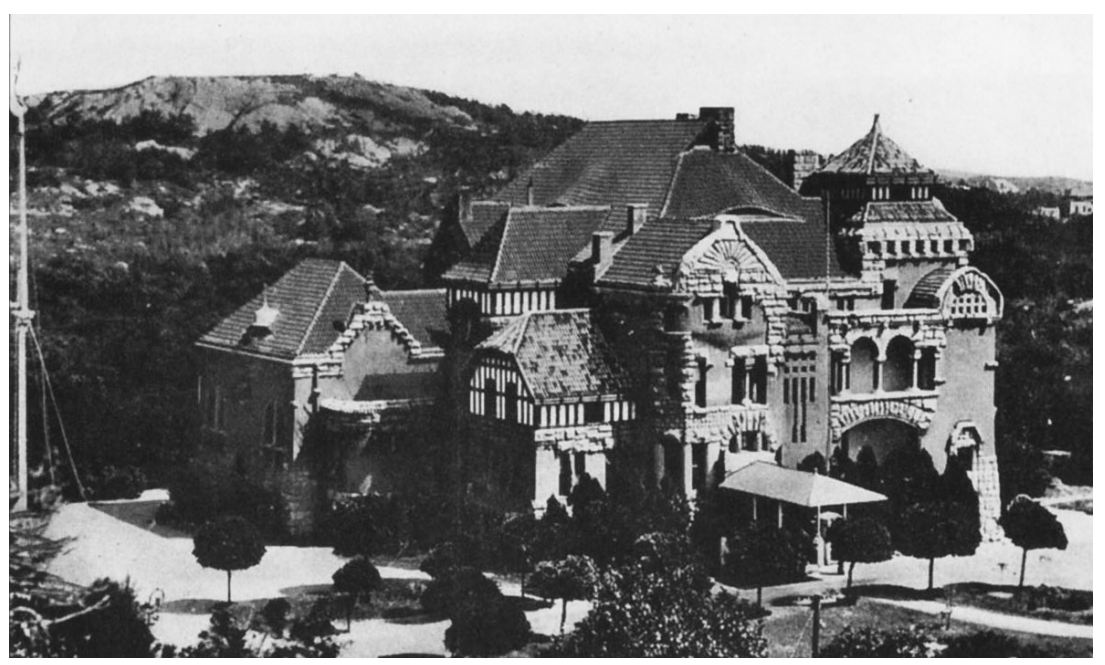

Figure 1. Governor's Residence (Shandong in China: Qingdao Past and Present, Tokyo: Alumni of Qingdao Japanese Junior High School, Committee of 77th Memorial of the Founding, 1993, 24) 
In this book he reminisces about a conversation with a Dutch family that drove him from Amsterdam to Utrecht:

1) Meanwhile, we came across an interesting thatched farmer's house. [...] I replied [to Mrs. Stempel's question] in an awkward wording. "Houses in any cities or those of the rich give only a uniform feeling, but at least farmer's houses have their national characteristics everywhere: that interests me." ${ }^{6}$

Horiguchi classifies Dutch architecture into three groups: traditional Amsterdam, modern Rotterdam and rural Utrecht. He probably referred to German architect Adolf Behne's (1885-1948) essay Holländische Baukunst in der Gegenwart [Dutch Architecture at Present] ${ }^{7}$ and an architectural magazine in the Netherlands Wendingen on discussing Amsterdam and Rotterdam. And more probably he had a close feeling toward his third group, Utrecht. Although he quotes that the greatest characteristics of Dutch architecture are in small urban houses and terraced housing for the poor, he seems to pay significantly larger attention to rural houses.

Horiguchi's expressionistic lecture on thatched roof supports our presumption. 2) [Architects in an artists' village Park Meerwijk] fired T squares and set squares to ignore the laws of architectural design. [...] They seceded from everything and how much a desire they expressed into architecture with bursting it in a modern ardor. Their flaming intrinsic power came to be expressed as a warping surface which had been suitably achieved with soft straw and sooty modest brick. $^{8}$

3) As contrasted to stovepipes stacked on the one side of the ridge makes a mass, a heavily sagged eave has a plump thickness of the thatch climbing with a slight undulation. ${ }^{9}$

4) In short, I have a special interest in the modern emergence of these thatched roofs first in Europe. ${ }^{10}$

Horiguchi did not find magnificence or monumentality in Dutch architecture. He regarded small houses, terraced houses and garden cities as contrasted with the German preference for monumentality.

It is noteworthy that Horiguchi named this tendency "Wabi and Sabi", and related it to the transition of construction of the Versailles: from the main palace of marble, mirror and gold to the Grand Trianon of simple stone and finally to the Petit Trianon of thatched brick. This was a recurring opinion that appeared in his essay in his first photo book on his residence published in 1927. Horiguchi found this transition from splendor to profound serenity also in the shift from Buddhist temples such as Kinkakuji and Ginkakuji to tearooms. He renamed the Wabi-Sabi as hi-toshitekina mono, or the non-urban, and defined the tendency as rural, indigenous and primitive element of architecture. 
The residence was built for the client's mistress and was named Shien So [fig.4]. It was built in Warabi, a northern periphery area in Tokyo in 1926. This project was not his first completion, but the book was the first of its type ever to be published in Japan. Horiguchi compared Shien So to urban houses in three features: urban problems, idyllic location and traditional natural materials such as thatch, wood or clay. ${ }^{11}$ Horiguchi emphasized contemporary demand for country life through its contrast with "exceptional, defective even now, artificial and sometimes abnormal" urban life. Home equipment for urban life under "various conventions among mass lives", "extreme disadvantages by artificially exaggerated economical limitations", and that was "circumscribed by many urgent problems" would have bothered him too much to start from the essence of life. While the residents were a couple without a child, Horiguchi mentioned the role of children as to "romanticize a residence" and designed a residence suitable for childbirth, care, rest, recuperation and retirement. In short, he created a residence to fulfill the needs of daily living.

What Horiguchi mentioned as the "urgent problems" of the urban area, must be regulatory issues. Based on governmental standpoints, mainstream architects had concerns about urban planning and harmony or unification of urban buildings. The Urban Building Law that covers hygiene, seismic structure and fire prevention (which meant endorsement of concrete) and the City Planning Law that enables land rezoning have been applied to six major cities in Japan since 1919. It was a rare exception that in Tokyo and Yokohama existed the buildings without proper foundations or bearings after the 1923 Earthquake. Horiguchi must have designed this rural residence with an emphasis on its quotidian nature to propose an antithesis to contemporary urban trends where compliance to technological and legal requirements is a must.
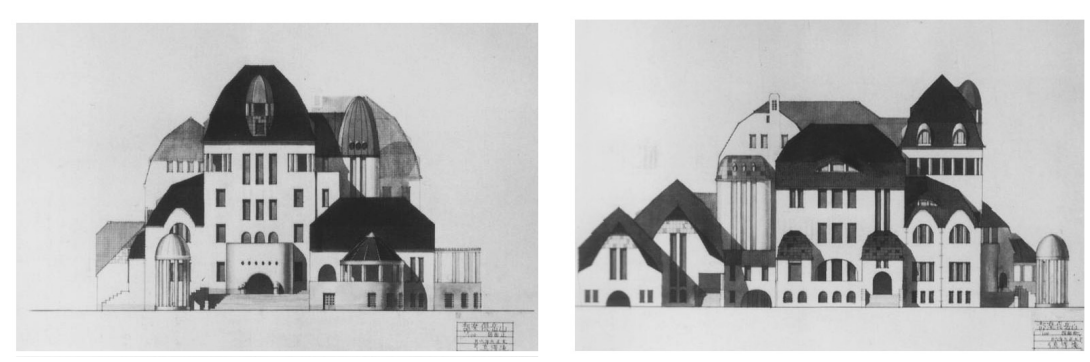

Figure 2. Takizawa Mayumi, Alpine Club Hall

(Cat. Ex. Rethinking Japanese Art in the Twentieth Century, Tsu: Mie Prefectural Art Museum, 1996, 74), diploma design to the Tokyo Imperial University. 
What confuses one about Horiguchi is that, while he developed an argument on non-urban architecture influenced by Dutch architecture, he stepped into Modernist architecture in the 1930s and simultaneously continued to study Japanese tearooms. There was even a time a master carpenter refused to work according to his design of Japanese rooms in his project. When trying to capture the relation between Dutch contemporary architecture and Japanese tearoom architecture based on this non-urban concept, one needs to focus on its relation with Modernist architecture.

What about tearooms that impressed Horiguchi so much?

5) I am interested in them not because they have a tradition inherited long, and I respect them not because [such tea masters as] Rikyu, Sotan and Ensyu cherished them, but because of the brilliant architectural ideas and techniques shown on them. It is because it will stimulate not only the rural huts but every architecture much. ${ }^{12}$

Presenting the particular to the established one could stress either its uniqueness or its universality. Horiguchi chose the latter, but he did not give up the uniqueness. Rather, he re-designed his discourse to fit what was universal, namely, the relation between Dutch and Japanese.

6) $[\ldots]$ even if there are a few exceptions, the almost all tearooms are thatched huts surrounded by a little open garden and most of the theme of their expression is a non-urban-ness, that is, a rural and mountain taste..$^{13}$

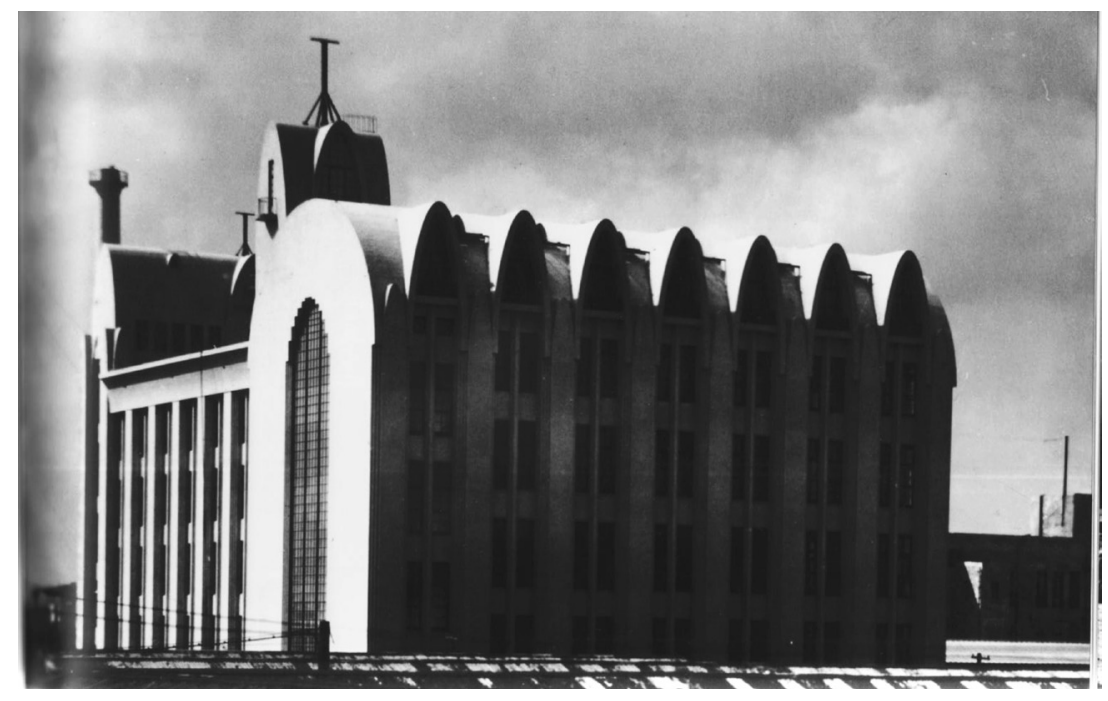


According to him, a "brilliant architectural idea" has an expression of "a nonurban-ness", and that connects Japanese tearooms to "every architecture". Horiguchi carefully claimed the global significance of the tearoom: he discussed that valuable tearoom architecture was not built by an unintentional, instinctive or natural process but through a consciousness of non-urban-ness.

7) A true rural or mountain hut was developed along with Nature, and its architectural appearance was not created with a consciousness of expression. [...It] stands exactly the opposite of the development of tearoom architecture while I have called it rural and mountainous. [...] we can say that tearoom architecture was developed at the requests of an intellectual class and an urban merchant class. ${ }^{14}$

Although he does not mention the original reference, his essay written in 1924 refers to German theory of art and shows his concerns about the ideal state of functionality and expression.

8) We find that the expression emerged from the theory of [Einheitskunstwerk, or unified works of art] and the realization of the theory of [Der grosse Bau, or The Great Architecture] are expressed, contemplated, and accomplished in Wabi and Sabi architecture. [...] When you observe a Mizuya [or water preparation area] in a tearoom, the fully heightened architectural expression, which displays a straight and beautiful harmony and a variation with the most practical adjustment and invention, is an integrated perfection of function and expression. ${ }^{15}$ Horiguchi argued that, when function and expression combine, the architecture would reign over to integrate all genres. This argument repeats in his essay written three years later.

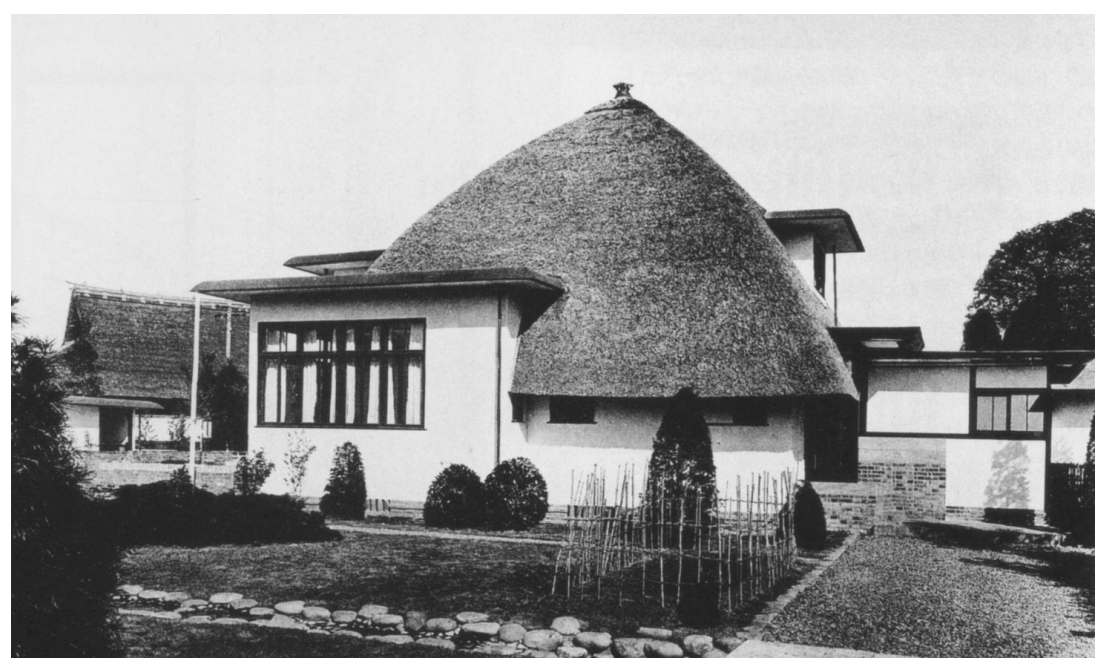

Fi gure 4. Horiguchi Sutemi, Shienso (Horiguchi Sutemi no "Nihon"

[ "Japan" in Horiguchi Sutemi], Tokyo: Shokokusha, 1997, 34). 
9) Sabi or Wabi is an expression which fulfills the function with these [natural] material and techniques, and which expresses naturally the internal depth of spiritual awakening with simple language of shapes prepared with the deepest contemplation. ${ }^{16}$

Another example would be his essay posted in the magazine Contemporary Architecture in 1940 which featured Sen no Rikyu, a 16th century tea master. Horiguchi was one of the pair editors of this issue.

10) His tearoom involves the problem of the nature of architecture itself, and is a message teaching us how to resolve a Sachlich requirement architecturally. ${ }^{17}$

Thus it is clear that he regarded the integration of function and expression as a basis of an expressive architecture, that is, a world-wide architecture in the late 1930 s.

The context above may clarify how Horiguchi came to invent his myth of the Parthenon experience.

11) [Sabi or Wabi] is not an expression like the Gothic which assumes a simple primitivism in outward appearances, but make a spiritual leap with an intensive excess. And it is not like the Greek Classics with an aim to make a beautiful harmony through the objective attentions to the details. But it is like the Gothic in terms of assuming a naïveté which is simple and appears even somewhat bizarre in its materials. And it is like the Greek Classics which assumes a sophisticated serenity with the depth of the peaceful spiritual awakening. ${ }^{18}$

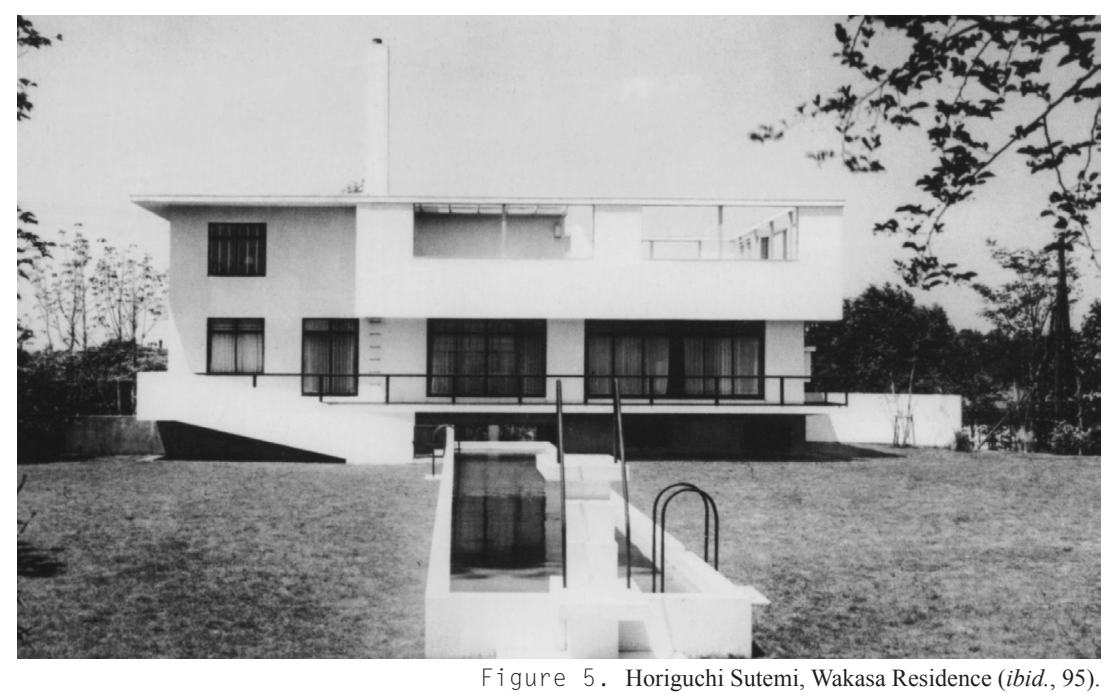


Wabi or Sabi has "a spiritual leap" and "a naïveté" but also "assumes a sophisticated serenity". In spite of his thought around his coming home from Europe, he came to see Greek Classic architecture as including the element his architecture would assume.

Horiguchi alleged the superiority of functionality but he did not prefer buildings that were built solely under material and construction constraints. $\mathrm{He}$ adopted flat roofs made of lumber in his design; should he choose reinforced concrete, there were less concern for roof leaks. He considered even a rooftop swimming pool in the Wakasa Residence in 1939 (Fig. 5), but gave it up due to government's regulation on concrete, thus only the flat roof for exercising and sunbathing was realized. When he was criticized for his irrational choice of lumber, he tried to defend himself.

12) Although it is wrong in terms of structure, when required we have to do it. It will stimulate the progress of architecture. The everyday life requires children's playground and drying clothes on the rooftops. Moreover, modern cities are lacking gardens. [...] Although it is difficult to build a flat roof of wood, I think doing it should be a duty of the architect. ${ }^{19}$

Although Horiguchi did not assert that this adoption of flat roof was an architect's expression, he obviously attributed a larger significance to his somewhat irrational choice than to ordinary material or construction restraints.

In this section it can be concluded that Horiguchi thoroughly explored the tearoom architecture and argued its functionality that met the needs of everyday life, which surpassed the material or construction requirements and at the same time was free from urban regulation. What remains is the relationship of Horiguchi and expression.

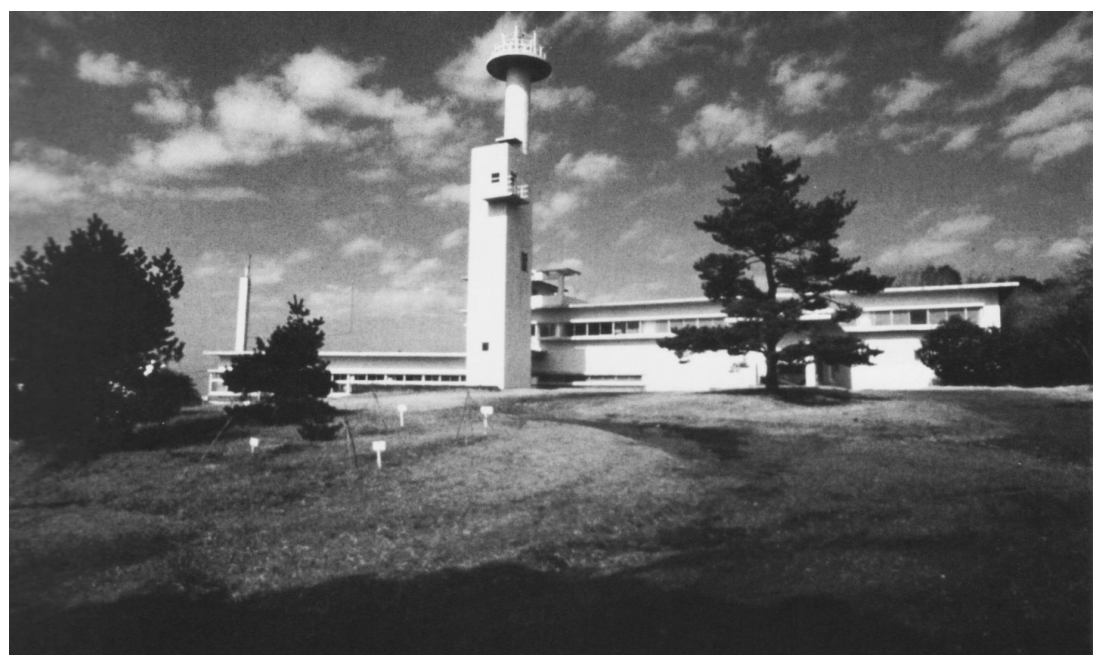

Figure 6. Horiguchi Sutemi, Oshima Meteorological Observatory (ibid., 102). 
GLOBAL MONUMENTALITY OF A SMALL ISLAND:

THE 1940S AND ITS PRECURSOR

Horiguchi compared contemporary architectures in the Netherlands and Germany based on monumentality in his essay in 1924. Then he adopted monumentality in his design of Oshima Meteorological Observatory in a volcano island $120 \mathrm{~km}$ to the southeast of Tokyo [fig. 6]. He declared that he was not conscious of any styles before its completion, as advocated by such contemporary architects as J. J. P. Oud, Gropius and Adolf Behne. But he admitted his design could assume a style a posteriori, and named it the "style without style".

Horiguchi argued that it was rare to place an exhibition room of geophysics ancillary to an observatory and it had a global significance. He thought it should assume a monumentality, though it was a practical Zweckbau, and he achieved it through building an observation tower as a point of expression with fulfilling sachlich requirements of the observation of winds, seismic instrumentation and radio communication and walking up and down of the staff to record data and to maintain the instruments. Horiguchi described his feelings on designing the tower and the building:

13) The indices for these functions to operate perfectly arrange and tighten the form in designer's imagination definitely. My heart has a tension to make form, color, and proportions beautifully constructed in these compositions and it penetrates and supports everything like a shadow for an object. Where this heart is not expressed would be a dead surface and a dead color and it does not make a building lively as a whole. ${ }^{20}$

Although we tend to regard a monument itself as a lifeless stone that resists people's oblivion, Horiguchi abstracted its monumentality through the filter of his expression and gave it to a modern Zweckbau.

It is known that Horiguchi was against the Teikan ("imperial crown") style which prevailed among Japanese public buildings then. People called them to be Japanese or Asian tastes in those days and deemed them appropriate outside and inside: the context in Asian cities; the collection of Asian artifacts when it was a museum. Of course, Horiguchi rejected such discussion.

14) We can say that what they call Japanese taste or Asian taste is usually an imitation of a style of wooden buildings into reinforced concrete or steel structure. ${ }^{21}$ 
Horiguchi says such architecture has put the priority of function and expression the other way around. He rejected the styles a priori and their mixture to adapt to his monument and based it solely on his own expression or integration.

But we can imagine another element of monumentality. There was a plan to celebrate the Olympic Games and World Expo in Tokyo in 1940 and the stadium and the collateral National History Museum were expected to take the Teikan Style. Horiguchi deemed this style to be under Chinese influence and argued that adopting this style would only intensify Sinocentrism. ${ }^{22}$ But what is important to mention here is his advocacy for monumentality that included a kind of expression.

15) In order that [the Cenotaph] has an expression to impress not only Japanese people but people in the world, its expanse and its style of expression should be world-wide judged. [...] It does not require such expression like today's Zweckbau as a pure monument. ${ }^{23}$

He classified a mere massive perpetual monument as a Zweckbau and stated that an appropriate monument should assume a global expression. Such expression could be a sculpture, a planted tree, or a garden. His famous essay in 1934 argued that the Japanese have a unique thought of the national monument: they had not required its material and its structure permanence, for example Ise Shrine. Aside from the argument of the specific national identity which Horiguchi frequently mentioned, the expression he preferred had an intensive strength that led to the global world. Now it has been made clear the relation between the international and the national or the local that he conceived.

Horiguchi has been a mystery who started as an Expressionist and then a Modernist and pursued a profound study of tearooms and dealt with Japanese Sukiya style, versioned tearooms in the midst of post-war modernism. However, one can say that Horiguchi took up both the functionality of everyday life and the monumentality with an expression as a vehicle of an architectural theory with global strength. Everyday life was released from the chains of urbanity such as structure, construction and regulation and monumentality was released from the chains of a literal historicism and a special functionality. This illuminates how the local becomes the international, and vice versa. 
Gregory Clancy, Earthquake Nation: The Cultural Politics of Japanese Seismicity, 1868-1930 (Berkeley: University of California Press, 2006) Isozaki Arata, Kenchiku ni okeru "Nihontekina Mono" - "Japaneseness" in Architecture (Tokyo: Shinchosha, 2003), 16-19. Harry Harootunian, Overcome by Modernity: History, Culture, and Community in Interwar Japan (Princeton: Princeton Univeristy Press, 2000). Sutemi Horiguchi, Gendai Oranda Kenchiku - Contemporary Dutch Architecture (Tokyo: Iwanami Shoten, 1924), 7. This point was first (re)discovered by Mikio Horikawa "Dutch Architectural Influence on Horiguchi Sutemi," JIA Lecture Summary (1989):10. Sutemi Horiguchi, Gendai Oranda Kenchiku - Contemporary Dutch Architecture (Tokyo: Iwanami Shoten, 1924), 5. Adolf Behne, "Holländische Baukunst in der Gegenwart," Wasmuths Monatshefte für Baukunst Jg.6 (1921/1922): H1/2, S.1f. Sutemi Horiguchi, Gendai Oranda Kenchiku - Contemporary Dutch Architecture, 16. Ibid., 18. 
Sutemi Horiguchi, "Kenchiku no Hi-Toshitekina Mono ni tsuite (On Non-Urban-ness in Architecture)," in Shien So Zushu (Album of Violet Haze Lodge), (Tokyo: Koyosha, 1927), 2-3. Ibid., 9.

Sutemi Horiguchi, "Chashitsu no Shisouteki Haikei to sono Kosei (Theoretical Backgrounds of Tearooms and their Compositions)," in Kenchiku Yoshiki Ronso (Symposium of Architectural Style), ed. Sutemi Horiguchi and Takaho Itagaki ed. (Tokyo: Rokumonkan, 1932a), 26. Ibid., 27.

Sutemi Horiguchi, "Kenchiku no Hi-Toshitekina Mono ni tsuite (On Non-Urban-ness in Architecture),"12.

Ibid., 10.

Sutemi Horiguchi, "Churei To no Hyogen to Sono Ichi Shian (The Expression of the Cenotaph and My Tentative Plan)," in Gendai Kenchiku (1940.4), 2.

Sutemi Horiguchi, Gendai Oranda Kenchiku - Contemporary Dutch Architecture (Tokyo: Iwanami Shoten, 1924), 11.

Nihon Kosaku Bunka Renmei (Japanese Werkbund). “Zadankai: Shin Nihon Kosaku Bunka Kensetsu no tameni (A Roundtable: for the Construction of Working Culture in the New Japan)," in Gendai Kenchiku (1939), 81.

Sutemi Horiguchi, "Shin Jidai Kenchiku no Shinwa Sonota (The Myth of Architecture in New Days, and Others)," in Kokusai Kenchiku (1939.2), 3.

Sutemi Horiguchi, "Chashitsu no Shisouteki Haikei to sono Kosei (Theoretical Backgrounds of Tearooms and their Compositions)," in Kenchiku Yoshiki Ronso (Symposium of Architectural Style), ed. Sutemi Horiguchi and Takaho Itagaki ed. (Tokyo: Rokumonkan, 1932a), 682. Sutemi Horiguchi, "Nihon no Gendai Kinen Kenzobutsuno Yoshiki ni tsuit (On the styles of Contemporary Monuments in Japan)," in Gendai Kenchiku (1939.6), 6.

Sutemi Horiguchi, "Churei To no Hyogen to Sono Ichi Shian (The Expression of the Cenotaph and My Tentative Plan)," in Gendai Kenchiku (1940.4),6.

Behne, Adolf. "Holländische Baukunst in der Gegenwart." in Wasmuths Monatshefte für Baukunst, Jg.6. Berlin: Ernst Wasmuth, 1921/1922.

Clancy, Gregory. Earthquake Nation: The Cultural Politics of Japanese Seismicity, 1868-1930. Berkeley: University of California Press, 2006.

Fujioka, Hiroyasu. Hyogensya Horiguchi Sutemi: Sogo Geijutsu no Tankyu (A Man of Expression Horiguchi Sutemi: A Quest for Unified Art). Tokyo: Chuo Koron Bijutsu Shinsya, 2009.

Harootunian, Harry. Overcome by Modernity: History, Culture, and Community in Interwar Japan. Princeton: Princeton Univeristy Press, 2000.

Horiguchi, Sutemi. Gendai Oranda Kenchiku (Contemporary Dutch Architecture). Tokyo: Iwanami Shoten, 1924.

Horiguchi, Sutemi. "Kenchiku no Hi-Toshitekina Mono ni tsuite (On Non-Urban-ness in Architecture).” In Shien So Zushu (Album of Violet Haze Lodge). Tokyo: Koyosha, 1927.

Horiguchi, Sutemi. "Chashitsu no Shisouteki Haikei to sono Kosei (Theoretical Backgrounds of Tearooms and their Compositions)." In Kenchiku Yoshiki Ronso (Symposium of Architectural Style), edited by Sutemi Horiguchi and Takaho Itagaki. Tokyo: Rokumonkan, 1932. 
Horiguchi, Sutemi. "Gendai Kenchiku ni Arawaretaru Nihon Syumi ni tsuite (On Japanese Taste Shown on Contemporary Architecture)," In Kenchiku Yoshiki Ronso (Symposium of Architectural Style), edited by Sutemi Horiguchi and Takaho Itagaki ed.Tokyo: Rokumonkan, 1932.

Horiguchi, Sutemi. "Kenchiku ni okeru Nihontekina Mono (The Japaneseness in Architecture). In: Shiso. Tokyo: Iwanami Shoten, 1934.

Horiguchi, Sutemi. "Shin Jidai Kenchiku no Shinwa Sonota (The Myth of Architecture in New Days, and Others)." In Kokusai Kenchiku, Tokyo: Kokusai Kenchikusya, 1939.

Horiguchi, Sutemi. "Nihon no Gendai Kinen Kenzobutsuno Yoshiki ni tsuite (On the styles of Contemporary Monuments in Japan).” In Gendai Kenchiku, Tokyo: Gendai Kenchikusya, 1939.

Horiguchi, Sutemi. "Churei To no Hyogen to Sono Ichi Shian (The Expression of the Cenotaph and My Tentative Plan).” In Gendai Kenchiku, Tokyo: Gendai Kenchikusya, 1940.

Horiguchi, Sutemi. "Rikyu to Gendai Kenchiku: 350nen Sai ni Atatte (Rikyu and Contemporary Architecture: on the Occasion of His 350th Anniversary)." In Gendai Kenchiku, Tokyo: Gendai Kenchikusya, 1940.

Horikawa, Mikio. "Dutch Architectural Influence on Horiguchi Sutemi”, JIA Lecture Summary, Tokyo: Japan Institute of Architecture, 1989. 


\section{GRAD KAO DRUŠTVENA SKULPTURA}

\section{Jale Erzen}

Argumenti u ovom radu pokušavaju da pokažu da je grad u osnovi društveni prostor i da su pre njegove fiksiarne materije u formi arhitekture i urbanih struktura ipak to ljudi koji izgrađuju bitan karakter i prisustvo grada. Ideja društeve skulpture je uzeta kao živopisna metafora koja se poziva na prethodni rad i ideje Jozefa Bojsa. Bojs je tvrdio da su događaji i postupci ljudi u gradu društvene skulpture i to je ilustrovao u svom čuvenom performansu čišćenja ulica sa svojim studentima. Grad pripada ljudima i gradovi su odgovornost svojih stanovnika. Zalažući se za to, ovaj rad se isto tako poziva na GEZI događaje u Istanbulu. Ovi argumenti vode do zaključka da će vitalnija i značajnija umetnost u budućnosti morati da se odnosi na urbani kontekst više nego na bilo šta drugo.

KLJUČNE REČI: DRUŠTVENA SKULPTURA, GRAD, AKTIVIZAM, DRUŠTVENO TELO, NOVA UMETNOST

\section{UMETNOST (IZ) ODVAJANJA: ESTETIKA OKO ZIDA}

\section{Zoltán Somhegyi}

Zid je neophodan arhitektonski element, koja odvaja a u isto vreme ujedinjuje, stvarajući strane, podele i mogućnost proboja. Koje estetske potencijale i kvalitete možemo da nađemo oko zida? Ponekad se skoncentrišemo više na ono što zid obuhvata, ali možemo stvarno sam zid da stavimo u fokus, na primer, prilikom ispitivanja zida u ruševnom stanju: kada čak bukvalno možemo da hodamo oko samostojećeg vajarskog predmeta, ili kada ga tumačimo kao predmet i medijum vajarskih intervencija. U ovom radu, uz pomoć nekih umetničkih dela želeo bih da ispitam ulogu, pojavnost i „korišćenje“ zida, i da pokažem neke zapažene primere gde su arhitekte i umetnici bili inspirisani da pronađu nova tumačenja ovog klasičnog arhitektonskog elementa.

KLJUČNE REČI: ZID, RUŠEVINE, PRIRODA, VAJARSKA INTERVENCIJA, SAVREMENA UMETNOST

\section{“INTERNACIONALNI" STIL ARCHITEKTURE U JAPANU TRIDESETIH GODINA: VERNAKULARNOST I MONUMENTALNOST}

\section{Daiki Amanai}

Nakon ovladavanja Zapadnom arhitekturom hiljadu devetso desetih, japanske vrhunske arhitekte su bile suočene sa dva problema: kreiranjem sopstvenog stila koji se bazira na japanskim tradicijama i klimatskim ili seizmološkim uslovima i obrazovanjem običnih ljudi da stvore ukus za arhitekturu izvan površne imitacije onog sa Zapada. Pre svega, jedan od elite i prvobitni ekspresionista arhitekta Horiguči Sutemi je diskutovao o ne-urban-nosti koja povezuje japanske čajane i holandske seoske kuće. To je izrazio putem svog modernističkog tiumačenja funkcije, svog iskustva u Holandiji i reakcijom protiv administrativnih stavova o gradu i arhitekturi iz dvadesetih godina. Drugo, uprksos svom ranijem udaljenom stanovištu o monumentalnosti, njegov zahtev za vrhunskim izražavnaje nekih projektovanih spomenika širom sveta je revitaliziralo njegovu sopstvenu sklonost. Naizgled njegovi stavovi prema monumentalnosti su se promenili i osobina spomenika koji su odavali počast žrtvama rata ili podizala nacionalni ugled bila je suprotstavljena "internacionalnoj" odlici moderne arhitekture. Iako ove poente mogu da prikriju njegovu doslednost, možemo da pronađemo njegov kontinuirani dualizam: jedno je funkcionalnost koja je prevladala nad arhitektonskim diskursom tog doba i Horiguči je isto tako smatrao a drugo je njegov izraz koji je lokalnoj vernikularnoj praksi obezbedio poziciju u svetu. Ovi argumenti nam omogućavaju da među moderne arhitekte iz tog doba ubacimo potencijalno razumevanje ali u novom svetlu. 